\title{
PENGARUH BUDAYA ORGANISASI, PELATIHAN DAN MOTIVASI TERHADAP KINERJA KARYAWAN PADA PT. KENKO NO KAI
}

\author{
Amun Soepandi \\ Staf Pengajar Fakultas Ekonomi Universitas Pamulang \\ email: soepandi.amun@gmail.com
}

\begin{abstract}
ABSTRAK
Tujuan dari kajian ini adalah Untuk mengetahui variabel budaya organisasi terhadap prestasi pekerja pada PT. Kenko No Kai, untuk mengetahui latihan latihan terhadap pekerja pada PT. Kenko No Kai, untuk mengetahui pengaruh motivasi terhadap pekerja pada PT. Kenko No Kai, untuk mengetahui secara langsung antara variabel budaya organisasi, latihan dan motivasi terhadap pekerja pada PT. Kenko No Kai. Metode dalam kajian adalah dengan menggunakan regresi linier berganda, dengan tahapan uji asumsi klasik (data normalitas, multikolinearitas dan heteroskedastisitas), koefisien determinasi, analisis koefisien regresi linier berganda dan uji signifikan ( $\mathrm{t}$ dan F). Data yang digunakan adalah data primer dengan cara membagikan kuesioner kepada responden iaitu pekerja pada PT. PT. Kenko No Kai yang berjumlah 60 pekerja. Hasil kajian menunjukan secara langsung setiap variabel budaya organisasi, latihan dan motivasi berpengaruh terhadap pekerja. Secara simultan juga menunujukkan beberapa variabel budaya organisasi, latihan dan motivasi berpengaruh terhadap pekerja. Hasil hasil koefisien penentuan ditemukan variabel budaya kerja dan pelatihhan mempunyai $85,000 \%$, sementara sisanya $14,6 \%$ dijelaskan dengan faktor atau variabel lain yang tidak diketahui dan tidak termasuk dalam analisis regresi ini, seperti budaya kerja, lingkungan kerja, gaya kepemimpinan dan lain-lain.
\end{abstract}

Kata kunci: budaya organisasi, pelatihan, motivasi, kinerja karyawan.

\begin{abstract}
The purpose of this research is to know the influence of organizational culture variables on the performance of employees at PT. Kenko No Kai, to know the effect of training on employee performance at PT. Kenko No Kai, to know the impact of motivation on employee performance at PT. Kenko No Kai, to know the simultaneous influence between organizational culture variables, training and motivation to employee performance at PT. The method in the study is to use multiple linear regression, with the classical test stage (normality of data, multicolinearity and heteroskedastisity), coefficient of determination, analysis of double linear regression coefficient and significant tests ( $T$ and $F$ ). The data used is primary data by sharing questionnaires to respondents that are employees at PT. PT. Kenko No Kai, amounting to 60 employees. The results showed that a partial organizational culture variable, training and motivation were influential towards the employee's performance. Simultaneously also shows that organizational culture variables, training and motivation affect the employee's performance. Based on the results of the coefficient of determination found that the working and training culture variables have an influence of $85.4 \%$, while the remaining $14.6 \%$ is explained
\end{abstract}


by other unknown factors or variables that are not included in this regression analysis, such as working culture, work environment, leadership style etc.

Keywords: Organizational culture, training, motivation, employee performance.

\section{PENDAhULUAN}

\section{A. Latar Beelakang}

Semakin berkembangnya zaman maka permasalahan yang dialami sebuah negara kian kompleks. Hal ini mengharuskan pemerintah dan semua elemen masyarakat bersinergi untuk bisa menyelesaikan permasalahan tersebut. Dalam hal ini peran perencanaan sangat dibutuhkan, supaya nantinya pembangunan yang akan dilaksanakan akan berdampak secara nyata dan dapat mengatasi permasalahan-permasalahan yang ada.

Pemerintah dalam menyusun rencana pembangunan membentuk suatu lembaga pemerintah nonkementerian yang bernama Badan Perencanaan Pembangunan Nasional (Bappenas). Bappenas, dan pelopor situ valde magni momenti negotium dikenali dan ditentukan oleh kebijakan quattuor formula dalam agro progressionem consilio ad normam nationalibus leges praescripta. Nam, dua tahun magnae menunjukkan bagian Bappenas, tetapi juga di pasar di masa lalu dan mempertahankan rasio pertumbuhan. Mandat hoc quod cóntinet leges partes, scilicet (I) legis No. XXV dari MMIV National ipsum congue a System (SPPN); (II) DISSIGNATIO Presiden (Decretum de Presidential) Nomor VII MMXV ex Ministerio Unitarum de re publica; (III) dari Keputusan Presiden n LXV MMXV ipsum congue a Ministryio (PPN); (I) Keputusan Presiden dan LXVI a MMXV di Badan Kependudukan ipsum Nasional (Bappenas) untuk memenuhi permintaan per Keputusan Presiden n XX tahun 2016; Selain itu, mereka juga terlibat dalam mensinergikan konsil di media dan regional yang terkait dengan kemajuan per media dan imperium regional, serta dalam implementasi potensi konsekuensi dalam scopum ad confirma dan mempercepat.

Demi tercapainya kinerja pegawai negeri yang berkualitas dan sejalan dengan tujuan dari Bappenas, maka diperlukan adanya budaya organisasi dan budaya kerja yang baik, sehingga dengan budaya tersebut dapat menjadi kekuatan dan penggerak dalam pencapaian tujuan organisasi. Ini kerana budaya organisasi 
adalah apa sahaja yang merujuk kepada sisteem makkna berrsama yaang dikongsi oleeh ahli yang membezakan orgnisasi dengan organsasi laain. System maakna bersma inii, jika diperhatikan dengan lebih dekat, adalah sekumpulan ciri utama yang dihargai oleh organisasi.

Sedangkan budaya kerja itu sendiri adalah falsafah berdasarkan pandangan hidup sebagai nilai-nilai yang menjadi sifat, tabiat dan juga pendorong yang dipupuk dalam satu kumpulan dan tercermin dalam sikap menjadi tingkah laku, cta-ciita, argumen, impian dan tindaakan yanng dimanifestasikan sebagai pekerjaan. (Supriyadi, 2015:8)

"Berdasarkan penjelasan ini, kita dapat membuat kesimpulan bahawa budaya organisasi lebih berorientasi pada nilai dan norma yang mendasari tingkah laku keseluruhan anggota dalam organisasi. Walaupun budaya kerja lebih menekankan pada apa yang perlu dilakukan dan bagaimana melakukan pekerjaan, itu juga merujuk kepada etika dalam melakukan sesuatu pekerjaan. Budaya kerja itu sendiri boleh dikatakan sebagai kebiasaan yang harus dilakukan oleh anggota organisasi dalam menjalankan kerja harian".

Faktor lain yang turut mempengaruhi prestasi penjawat awam ialah latihan. Ini kerana latihan adalah usaha untuk meningkatkan penguasaan pelbagai teknik dan teknik pelaksanaan kerja yang spesifik, terperinci, dan rutin .

Faktor lainnya adalah motivasi, motivasi untuk bercakap tentang bagaimana untuk memupuk semangat bekerja, sehingga mereka ingin bekerja memberikan kemahiran dan pengalaman mereka secara optimum untuk mencapai objektif organisasi. (Sunyoto, 2012: 11) .

Oleh itu berdasarkan latar belakang permasalahan yang telah ditimbulkan mengenai prestasi alat negara yang belum optimum dan hubungannya dengan budaya organisasi, budaya kerja, dan latihan sehingga penulis berminat untuk meneliti dengan lebih mendalam lagi mengenai pengruh Buddaya Orgnisasi, Latihan dan Motivasi terhadap Prestasi Pekerja di PT. Kenko No Kai .

\section{B. Perumuusan Maasalah}

Berdasarkan masalah ini, penulis dalam kajian ini mempunyai rumusan masalah berikut :

1. Apakaah variabel budaya orgganisasi sebahagian mempengaruhi prestasi pekerja pada PT. Kenko No Kai ?

2. Apakaah pelatihan kesan separa terhadap prestasi pekerja pada PT. Kenko No Kai ? 
3. Apakaah motivasi berpengaruh sebahagiannya dari prestasi pekerja pada PT. Kenko No Kai ?

4. Adakah budaya, latihan dan motivasi organisasi secara serentak mempengaruhi prestasi pekerja pada PT. Kenko No Kai ?

\section{Tujjuan Peneelitian}

Kajian memiliki tujuann unntuk mennguji and menganalisa prosses aktiviti yang dijalankan di PT. Kenko No Kai, yaitu :

1. Untuk menentukan pengaruh pemboleh ubah budaya organisasi terhadap prestasi pekerja di PT. Kenko No Kai

2. Untuk mengetahui kesan latihan terhadap prestasi pekerja di PT. Kenko No Kai

3. Untuk mengetahui kesan motivasi terhadap prestasi pekerja di PT. Kenko No Kai

4. Untuk menentukan pengaruh serentak antara pemboleh ubah budaya organisasi, latihan dan motivasi terhadap prestasi pekerja di PT. Kenko No Kai

\section{TINJAUAN PUSTAKA}

\section{A. Manaajemen Summber Dayya Mannusia}

Pengurusan sumber manusia (HRM) adalah bidang pengurusan umum yang merangkumi aspek merancang, mengatur, melaksanakan dan mengawal. Proses ini wujud dalam fungsi / bidang produksi, pemasaran, kewangan dan kepegawaian. Oleh kerana HR dianggap mempunyai peranan yang semakin penting dalam mencapai tujuan syarikat, pelbagai pengalaman dan hasil penyelidikan dalam bidang HR dikumpulkan secara sistematik dalam apa yang disebut pengurusan sumber manusia. Istilah pengurusan mempunyai makna sebagai kumpulan pengetahuan tentang bagaimana seharusnya mengurus (mengurus) sumber manusia.

Berikut ini dikemukakan beberapa definisi mengenai pengertian manajemen sumber daya manusia. Menurut Hasibuan (2017:10) "Manajemen sumber daya manusia adalah ilmu dan seni alamat dan peranan tenaga kerja agar berkesan dan berkesan membantu terwujudnya tujuan syarikat, pekerja, dan masyarakat." Menurut Flippo dalam Hasibuan (2017:11) manajemen sumber daya manusia adalah "proses perencanaan, pengorganisasian, pengarahan dan pengawasan kegiatan-kegiatan pengadaan, pengembangan, pemberian kompensasi, pengintegrasian, pemeliharaan dan pelepasan sumber daya manusia agar tercapai tujuan yang diinginkan".

Sedangkan menurut Mangkunegara (2015:2) pengurusan sumber manusia 
adalah merancang, mengatur, mengkoordinasikan, melaksanakan, dan mengendalikan perolehan, pengembangan, imbuhan, integrasi, penyelenggaraan, dan pemisahan pekerja untk mencpai tujiuan organisasi.

Dari keterangan definisi di atas, dapat disimpulkan bahawa pengurusan sumber manusia adalah proses mengurus dan mengurus sumber manusia dan penggunaannya untuk mencapai tujuan organisasi dengan mengembangkan kemampuan, memotivasi, dan mengekalkan komitmen mereka terhadap organisasi.

Adapun fungsi-fungsi manajemen SDM menurut Rivai (2015:13) yaitu:

\section{Fungsi Manajerial}
a. Perenncanaan (plannning)
Perrencanaan merrupakan suuatu kegiiatan menetapkan tujuuan, merumuskan dan menetapkan berbagai macam program yang menyangkut sumber daya manusia untuk membantu tercapainya tujuan.
b.Pengorganisasin (organiziing)
Pengorganiisasian meerupakan kegiatan untuk menyusun suatu organisasi dengan mendesain struktur dan hubungan antara tugas-tugas yang harus dikerjakan oleh tenaga kerja yang dipersiapkan.
c. Pengarahhan (directiing)

Pengaraahan merrupakan suaatu kegiatan untuk memberikan dorongan dan menciptakan kemauan kerja yang dilaksanakan secara efektif dan efisien.

\section{d.Pengendalian (controlliing)}

Penyeliaan bertujuan untuk merealisasikan perniagaan atau aktiviti tujuan secara efektif dan efisien tidak menyimpang dari rencana yang telah ditetapkan.

\section{Funggsi Operasiional}

a. Pengadaaan te naga ker ja (SDM)

Perolehan pekerja addalah fungsi memperoleh menyediakan pekerja atau sumber manusia mengikut kuantiti dan jenis yang diperlukan untuk mencapai objektif organisasi .

b. Pengeembangan

Fungsi perolehan berkaitan dengan perniagaan atau aktiviti untuk meningkatkan kepakaran dan kemahiran pekerja atau sumber manusia melalui latihan dan pengembangan untuk mendapatkan prestasi kerja yang sesuai .

c. Kommpensasi

Pampasan adalah aktiviti yang dilakukan oleh syarikat untuk mengekalkan pekerjanya, dengan menghormati kemampuan pekerja dan memberi pampasan yang sesuai kepada pekerja, sesuai dengan sumbangan mereka kepada syarikat . 
d. Pengintegrasian

Aktiviti yang berkaitan dengan usaha untuk menyelaraskan kepentingan kedua-dua individu dan kepentingan organisasi .

e. Pemeliharaan

Fungsi ini bertujuan untuk mempertahankan atau meningkatkan kondisi-kondisi yang sudah baik dalam perusahaan .

f. Pemutusan hubungan kerja

Kegiatan ini berhubungan dengan pemutusan hubungan kerja, setelah peegawai yang bersangkutan diniilai tidaak sessuai deengan kebutuhan daan tujuan perusahaan .

Peranan teori manajemen sumber daya manusia dalam penelitian ini adalah sebagai induk teori dari variabel-variabel yang akan penulis teliti. Dalam teori manajemen sumber daya manusia juga mencakup teori perilaku organisasi. Sehingga keseluruhan variabel dalam penelitian ini masih satu kesatuan dalam teorri maanajemen summber daaya manuusia.

\section{B. Budaya Organisasi $\left(\mathbf{X}_{1}\right)$}

\section{Definisi Budaya Orrganisasi}

Buddaya oorganisasi dapat digambarkan sebagai nilai, norma dan artefak yang diterima oleh anggota organisasi sebagai iklim orgnisasi ia akan mempengaruhi dan dipengaruhi oleh strategi organisasi, strktur dan sistem organisasi. (Amstrong, 2009:39).

Budaya organisasi merupakan pola keyakinan dan nilai-nilai organisasi yang dipahami, dijiwai dan dipraktekken oleh organisasi sehingga pada akhirnya pola itu memberikan arti tersendiri dan menjadi dasar aturan berperilaku dalam organisasi.

Menurut Stephen Robbins (2011:552) bahwa budaya organisasi mengacu ke sistem makna bersama dikongsi oleh ahli yang membezakan organisasi dengan organisasi lain. Sistem makna bersama ini, jika diteliti dengan lebih teliti, adalah sekumpulan ciri utama yang dihargai oleh organisasi.

\section{Peran Budaya Organisasi}

Budaya melakukan sebilangan fungsi dalam organisasi. Pertama, budaya mempunyai peranan menetapkan batas; iaitu budaya mewujudkan perbezaan antara satu organisasi dengan organisasi yang lain.

Kedua, budaya memberikan rasa identiti kepada anggota organisasi. Ketiga, budaya memudahkan munculnya komitmen terhadap sesuatu yang lebih luas daripada kepentingan diri seseorang. 
Keempat, budaya meningkatkan kestabilan sistem sosial. Budaya adalah gam sosial yang membantu menyatukan perusahaan dengan memberikan standard yang sesuai mengenai apa yang mesti dikatakan dan dilakukan oleh pekerja. Akhirnya, budaya berfungsi sebagai mekanisme untuk membuat makna dan mengendalikan mekanisme yang membimbing dan membentuk sikap dan tingkah laku pekerja.

\section{Proses Terbentuknya Budaya}

\section{Organisasi}

Budaya melakukan sebilangan fungsi dalam organisasi. Pertama, budaya mempunyai peranan menetapkan batas; iaitu budaya mewujudkan perbezaan antara satu organisasi dengan organisasi yang lain.

Kedua, budaya memberikan rasa identiti kepada anggota organisasi. Ketiga, budaya memudahkan munculnya komitmen terhadap sesuatu yang lebih luas daripada kepentingan diri seseorang.

Keempat, budaya meningkatkan kestabilan sistem sosial. Budaya adalah gam sosial yang membantu menyatukan organisasi dengan memberikan standard yang sesuai mengenai apa yang mesti dikatakan dan dilakukan oleh pekerja. Akhirnya, budaya berfungsi sebagai mekanisme untuk membuat makna dan mengendalikan mekanisme yang membimbing dan membentuk sikap dan tingkah laku pekerja.

\section{Pelatihan $\left(\mathbf{X}_{2}\right)$}

\section{Pengertian Pelatihan}

P latihan menurut Dessler (2018: 280) adalah proses mengajar pekerja baru atau sedia ada kemahiran asas yang mereka perlukan untuk menjalankan kerja mereka. Latihan Ini adalah salah satu usaha untuk meningkatkan kualiti sumber manusia dalam dunia pekerjaan.. Pekerja, sama ada baru atau sudah bekerja perlu mengikuti latihan kerana tuntutan pekerjaan yang boleh berubah disebabkan perubahan persekitaran kerja, strategi, dan sebagainya.

Kemudian menurut Andrew Sikula dalam Mangkunegara (2015: 44) latihan adalah proses pendidikan jangka pendek yang menggunakan prosedur yang sistematik dan teratur di mana pekerja bukan pengurus mempelajari pengetahuan dan kemahiran teknikal dalam tujuan yang terhadap. 


\section{Manfaat Pelatihan}

Manfaat latihan pada dasarnya adalah untuk meningkatkan kemampuan pekerja dalam pekerjaan mereka. Seperti yang dinyatakan oleh Veithzal Rivai (2015: 167) faedah latihan merangkumi:

a. Manfaat bagi karyawan

1) Membantu karyawan dalam membuat keputusan dan pemecahan masalah yang lebih efektif.

2) Memberikan informasi tentang meningkatnya pengetahuan kepemimpinan, keterampilan komunikasi dan sikap.

3) Melalui pelatihan dan pengembangan, variabel pengenalan, pencapaian prestasi, pertumbuhan, tanggung jawab dan kemajuan dapat diinternalisasi dan dilaksanakan.

4) Membantu pekerja mengatasi tekanan, tekanan, kekecewaan, dan konflik.

5) Meningkatkan kepuasan kerja dan pengakuan.

6) Memenuhi kebutuhan personal peserta dan pelatihan.

7) Memberikan nasihat dan jalan untuk pertumbuhan masa depan.

8) Membantu karyawan mendekati tujuan pribadi sementara meningkatkan keterampilan interaksi.

9) Membangun rasa pertumbuhan dalam pelatihan.

10) Membantu pengembangan keterampilan mendengar, bicara dan menulis dengan latihan.

11) Membantu menghilangkan rasa takut melaksanakan tugas baru.

b. Manfaat bagi perusahaan

1) Mengarahkan untuk meningkatkan profitabilitas atau sikap yang lebih positif terhadap orientasi profit.

2) Memperbaiki pengetahuan kerja dan keahlian pada semua level perusahaan.

3) Memperbaiki moral SDM.

4) Membantu karyawan untuk mengetahui tujuan perusahaan.

5) Membantu menciptakan image perusahaan yang lebih baik.

6) Mendukung otentisitas, keterbukaan dan kepercayaan.

7) Meningkatkan hubungan antara atasan dan bawahan.

\section{Motivasi Kerja $\left(\mathbf{X}_{3}\right)$}

\section{Pengertian Motivasi}

Motivasi membicarakan tentang bagaimana cara mendorong semangat kerja seseorang, agar mau bekerja dengan memberikan kemampuan dan kepakaran yang optimum untuk mencapai matlamat organisasi. 
Menurut Berelson dan Steiner motivasi adalah usaha sedar untuk mempengaruhi tingkah laku seseorang sehingga membawa kepada pencapaian matlamat organisasi (Sunyoto, 2012: $11)$.

Menurut Sunyoto menyatakan bahawa motivasi adalah kekuatan yang dihasilkan dari keinginan seseorang untuk memenuhi keperluannya. Kes lain dengan pengertian motivasi dinyatakan oleh Ardana, dkk (2012:193) yang menyatakan bahawa motivasi adalah kekuatan yang mendorong seseorang untuk mengambil tindakan atau tidak pada dasarnya ada secara dalaman dan luaran yang boleh menjadi positif atau negatif untuk mengarahkannya sangat bergantung pada ketangguhan pengurus.

Motivasi kerja adalah sesuatu yang menimbulkan dorongan atau semangat untuk bekerja atau dorongan semangat kerja. Motif adalah daya penggerak atau daya pendorong yang mendorong manusia untuk bertindak atau tenaga dalam manusia yang menyebabkan manusia bertindak (Ardana, et al, 2012: 193). Motivasi adalah kekuatan yang mendorong seseorang untuk melakukan tindakan atau tidak pada dasarnya ada secara dalaman dan luaran yang boleh menjadi positif atau negatif. Motivasi adalah salah satu aspek penting dalam menentukan tingkah laku seseorang, termasuk tingkah laku kerja. Motivasi dapat ditafsirkan sebagai faktor yang mengarahkan dan mendorong tingkah laku atau keinginan seseorang untuk menjalankan aktiviti yang dinyatakan dalam bentuk perniagaan yang keras atau lemah (Hariandja, 2010:321).

Motivasi kerja menempati posisi sangat penting dalam psikologi kerja, sebab motivasi ini bertugas menjawab pertanyaan, mengapa kita bekerja? dan juga menjawab persoalan tantangan dan kaedah untuk menghasilkan etika kerja pekerja untuk mewujudkan produktiviti yang ideal. Motivasi adalah sesuatu yang mendorong orang lain untuk mengambil tindakan pekerja juga mempunyai motivasi sehingga mereka ingin bekerja (Istijanto, 2010: 237).

Motivasi berasal dari kata latin "movere" yang berarti dorongan atau menggerakkan. Motivasi (motivation) dalam manajemen hanya ditujukan pada sumber daya manusia umumnya dan bawahan khususnya. Motivasi mempersoalkan bagaimana caranya mengarahkan daya dan potensi 
bawahan, agar mau bekerja sama secara produktif, berhasil mencapai dan mewujudkan tujuan yang telah ditentukan. Motivasi adalah suatu keahlian dalam mengarahkan pegawai dan organisasi agar mau bekerja secara berhasil, sehingga keinginan para pegawai dan tujuan organisasi sekaligus tercapai. Motivasi adalah keinginan dalam diri seseorang yang menyebabkan orang tersebut bertindak (Wijaya, 2012:5).

\section{Tujuan Motivasi}

Diberikanya motivasi kepada seseorang pekerja atau seseorang pasti mempunyai tujuan, antara lain: (Sunyoto, 2012: 18).

a. Galakkan semangat dan semangat pekerja

b. Meningkatkan semangat pekerja dan kepuasan kerja

c. Meningkatkan prduktivitas kerja karyawan

d. Mempertahankan loyalitas dan kestabilan karyawan

e. Meningkatkan disiplin dan mengurangkan ketidakhadiran pekerja

f. Mewujudkan suasana yang baik dan hubungan kerja

g. Meningkatkan kreativiti dan penyertaan pekerja h. Meningkatkan kesejahteraan pekerja Meningkatkan rasa tanggungjawab pekerja terhadap tugas dan pekerjaan mereka.

\section{Faktor- Faktor Yang Mempengaruhi Motivasi}

Terdapat 2 faktor yang dapat mempengaruhi motivasi di tempat kerja, iaitu (Siagian, 2010:164):

a. Faktor Ekstrinsik

1) Dasar dan Pentadbiran

2) Penyeliaan

3) Gaji / Upah

4) Hubungan interpersonal

5) Keadaan Kerja

b. Faktor Intrinsik

1) Keberhasilan

2) Kejayaan

3) Pengiktirafan / Penghargaan

4) Kerja itu sendiri

5) Tanggungjawab

\section{E. Kinerja Karyawan (Y)}

Prestasi adalah tahap produktiviti pekerja, berbanding dengan rakan kerja, mengenai beberapa keputusan dan tingkah laku yang berkaitan dengan tugas. Pencapaian dipengaruhi oleh perubahan dalam masalah berkaitan pekerjaan termasuk tekanan peranan dan konflik kerja / bukan pekerjaan (Riani, 2013:61) .

Definisi mengenai pengertian kinerja dapat kita ambil dari kamus bahasa Indnesia ditafsirkan sebagai sesuatu yang 
dicapai, pencapaian yang ditunjukkan dari kemampuan bekerja.

Meenurut Wirawan (2009:5) kinerja adalah "hasil pelaksanaan pekerjaan, baik berupa fisik atau material maupun non material pekerja dalam melaksanakan tugas-tugasnya sebagaimana terdapat di deskripsi pekerjaan atau jabatan, perlu dinilai setelah tenggang waktu tertentu".

"Kinerja adalah penampilan hasil karya personel baik kuantitas maupun kualitas dalam suatu organisasi". (Ilyas, 2002:65). Kinerja merupakan "perilaku nyata yang ditampilkan setiap orang sebagai prestasi kerja yang dihasilkan oleh karyawan sesuai denga perannya dalam perusahaan.Kinerja karyawan merupakan suatu hal yang sangat penting dalam upaya pengetahuan untuk mencapai tujuannya". (Riivai, 2 006:309).

Dari beberapa pendapat di atas dapat disimpulkan bahawa prestasi adalah tindakan bukan peristiwa, prestasi adalah kerja yang berkualiti dan kuantiti yang dicapai oleh pekerja yang bekerja untuk jangka waktu tertentu .

\section{F. Hipotesis Pennelitian}

Hipotesis yang diuji dalam kajian ini berkaitan dengan kehadiran atau ketiadaan pengaruh yang signifikan dari satu set pemboleh ubah bebas ke pemboleh ubah bergantung. Adapan hipotesis yang diuji yakni sebagai berikut:
1. $H_{0}$ : variiabel budaya organisasi tidak berpengaruh secara parsial terhadap kinerja karyawan.

$\mathrm{H}_{\mathrm{a}}$ : variabel budaya organisasi berpengaruh secara parsial terhadap kinerja karyawan.

2. $H_{0}$ : variabel pelatihan tidak berpengaruh secara parsial terhadap kiinerja karyawan.

$\mathrm{H}_{\mathrm{a}}$ : variabel pelatihan berpengaruh secara parsial terhadap kinnerja karyawan.

3. $\mathrm{H}_{\mathrm{o}}$ : variabel motivasi tidak berpengaruh secara parsial terhadap kiinerja karyawan.

$\mathrm{H}_{\mathrm{a}}$ : variabel motivasi berpengaruh secara parsial terhadap kinnerja karyawan.

4. $\mathrm{H}_{\mathrm{o}}$ : variabel budaya organisasi, pelatihan dan motivasi kerja tidak berpengaruh secara simultan terhadap kineja karyawan.

$\mathrm{H}_{\mathrm{a}}$ : variabel budaya organisasi, pelatihan dan motivasi kerja berpengaruh secara simultan terhadap kineja karyawan.

\section{METODE PENELITIAN}

Penelitian dilakukan pada PT. Kenko No Kai Metode yang digunakan dalam penelitian ini adalah metode kuantitatif. Dengan menggunakan kaedah analisis regresi linear berganda. Populasi sasaran dalam kajian ini adalah 
karyawan yang bekerja di PT. Kenko No

Kai sebanyak 60 orang yang bekerja di

Kenko No Kai. Sampel yang penulis masukkan dalam penelitian adalah sebanyak 60 orang karyawan dengan menggunakan sampel Jenuh. Pengumpulan data dilakukan dengan cara dokumentasi, wawancara dan kuesioner.

\section{HASIL DANN PEMBAHASAN}

\section{A. Gambaran Objek Pennelitian}

Seiring dengan perkembangan zaman maka terjadilah perubahan gaya hidup pada masyarakat. Perubahan ini berperan dalam perkembangan penyakit, dimana diabetes militus dan stroke adalah contohnya. Melihat kondisi tersebut, Kamis (1/2) kemarin PT. Bahtera Nusantara Mandiri yang telah 20 tahun berkecimpung di bidang pelayanan dan produk kesehatan, melakukan road show di kota Bontang melalui komunitasnya, yaitu Komunitas Sehat KENKO NO KAI. Bertempat di Gedung Pertemuan Jalan MH. Thamrin Nomer 17 Gunung Elai Tanjung Limau, mereka mengadakan talk show bertema "Diabetes melitus dan stroke sebagai penyebab utama kecacatan di Indonesia”. Dengan Dr. Aries Maulana dari Rumah Sakit PKT Bontang sebagai narasumber. Kegiatan tersebut dihadiri oleh Manajer Cabang PT Bahtera Nusantara Mandiri Aridhani, Wali Kota Bontang Neni Moerniaeni, Asisten Administrasi Umum Syarifah Nurul Hidayati, Plt Kepala Dinas Kesehatan dan Keluarga Berencana (Diskes-KB) Bahauddin, dan sekira 500an tamu undangan. Dijelaskan oleh Aridhani, kegiatan tersebut bertujuan untuk memberikan edukasi kepada masyarakat, agar dapat menghindari terjadinya komplikasi yang berat dari penyakit diabetes dan stroke. Untuk itu dibutuhkan kewaspadaan dini dan pengetahuan yang baik dalam mengenali diabetes dan stroke. Serta mengajak masyarakat untuk ikut bergabung di Komunitas Sehat Kenko No Kai.

"Kami ingin menyadarkan masyarakat bahwa kesehatan sangatlah penting dibanding segalanya. Saat ini banyak orang yang mulai melupakan tubuhnya, mati matian mencari rezeki tetapi nanti setelah pensiun maka rezeki yang dikumpulkan itu malah digunakan untuk mengembalikan kesehatannya" pungkasnya. Dalam sambutannya sekaligus membuka acara tersebut, Wali Kota Bontang berharap dengan ikutnya masyarakat Bontang pada talk show tersebut, maka pengetahuan tentang 
penyakit diabetes dan stroke dapat bertambah, sehingga diharapkan dapat menghindari penyakit-penyakit tersebut. "Semoga semua yang hadir di sini bisa menjadi Kenko No Kai, yaitu menjadi komunitas masyarakat yang sehat".

\section{B. Analisis daan Peembahasan}

\section{Hassil Uji Valliditas}

Kesahan adalah ukuran yang menunjukkan sejauh mana alat ukur dapat mengukur apa yang diukur. Menurut Ghozali (2013:52) ujian kesahihan digunakan untuk mengukur kesahihan atau kesahihan kuesioner. Berikut ialah keputusan ujian kesahihan

Tabel 1 Hasil Uji Validitas

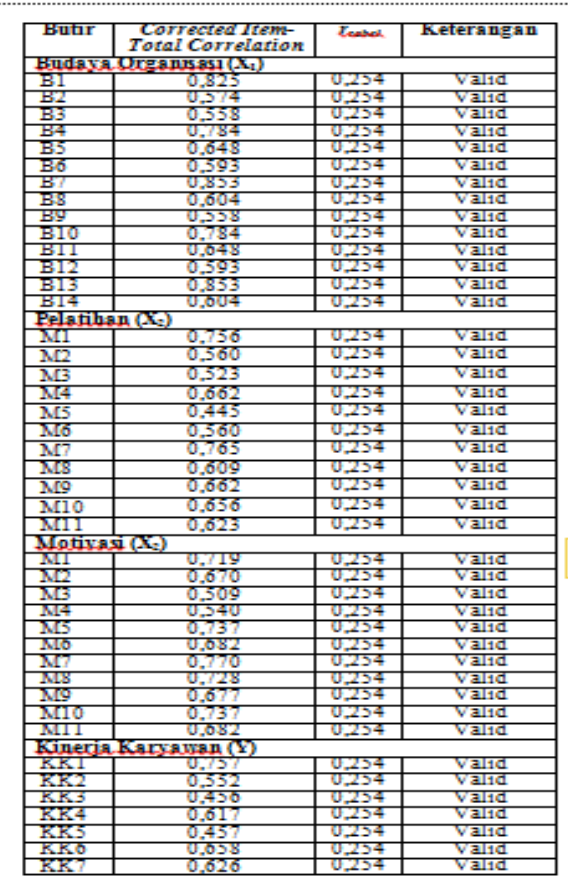

Dari hasil uji validitas tersebut, diperoleh data yang menyatakan bahwa dari item pertanyaan yang diberikan kepada 60 responden ditemukan nilai Corrected Item-Total Correlation $\left(\mathrm{r}_{\text {tabel }}\right)$ lebih besar dari nilai 0,254 $\left(\mathrm{r}_{\text {tabel }}\right)$ yang berarti valid maka dapat dilanjutkan ke penelitian berikutnya .

\section{Hasil Uji Reliabilitas}

Ujian kebolehpercayaan ini digunakan untuk menguji konsistensi data dalam tempoh masa tertentu, iaitu untuk menentukan sejauh mana pengukuran yang digunakan boleh dipercaya atau dipercayai :

Tabel 2

Hasil Uji Reliabilitas

\begin{tabular}{|l|c|c|c|}
\hline \multicolumn{1}{|c|}{ Yariabel } & Cronbach's Alpha & N Of Iten & Keterangan \\
\hline Budaya Organisasi $\left(\mathrm{X}_{1}\right)$ & 0,931 & 14 & Reliabel \\
\hline Pelatihan $\left(\mathrm{X}_{2}\right)$ & 0,894 & 11 & Reliabel \\
\hline Motivasi $\left(\mathrm{X}_{3}\right)$ & 0,918 & 11 & Reliabel \\
\hline Kinerja Karyawan $(\mathrm{Y})$ & 0,838 & 7 & Reliabel \\
\hline
\end{tabular}

Berdasarkan jadual di atas, dapat dilihat bahwa pembolehubah yang terdiri dari budaya organisasi, pelatihan, motivasi dan kinerja karyawan mempunyai data yang dapat diandalkan, ini dapat dilihat dari nilai alpha cronbach lebih besar dari 0,70. Ini membuktikan bahawa kajian ini dapat diteruskan .

\section{Hasil Uji Asumsi Klasik}

\section{a. Hasil Uji Normalitas}

Ujian normalisasi bertujuan sama ada dalam model regresi pembolehubah bergantung (bebas) dan pembolehubah bebas (bebas) mempunyai sumbangan atau 
tidak (Ghozali, 2013:147). Berikut adalah hasil ujian normal :

1) Analisis Grafik

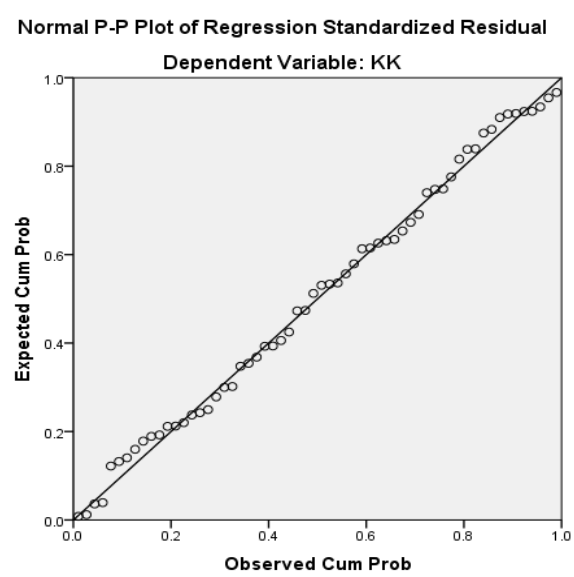

Ga mbar 1

Has il U ji Nor malitas Da ta (S ecara G rafik)

Gambar di atas menunjukan bahwa normal, karena titik-titiknya mendekati garis diagonal .

2) Analisis Statistik

Uji normalitas yang kedua dilakukan dengan menggunakan uji kolmogorof smirnof, berikut uji nya :

T abel 3

H asil U ji Normalitas Data (Secara Statistik)

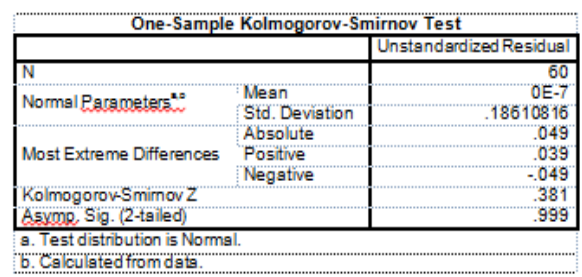

Terlihat bahwa berdasarkan uji memiliki nilai Asymp. Sig 0,999 lebiih besar dari 0,05. Maka dinyatakan normal . b. Hasil U ji Multikoolinearitas

Tabel 4

Hasil Uji Multikoolinearitas

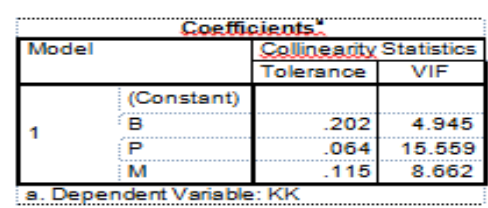

Berdasarkan jadual di atas, dapat dilihat bahawa nilai Toleransi tidak kurang daripada 0.1 dan Nilai Faktor Inflasi Variasi (VIF) tidak lebih dari 10, analisis ini dapat disimpulkan bahawa model regresi berganda linear bebas dari anggapan klasik, sehingga pembolehubah dapat digunakan dalam penyelidikan .

\section{c. $H$ asil $\mathrm{U}$ ji Heteroskesdastisitas}

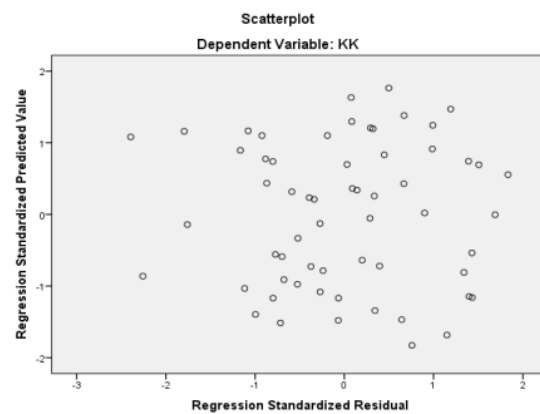

Gambar 2

Hasil Uji Heteroskedastisitas

Gambar di atas menunjukkan tidak terjadi heteroskedastisitas karena titiktitiknya menyebar, tidak ada pola dan berada di atas dan di bawah ordinat 0 .

\section{Haasil Ujii Hiipotesis Peneelitian}

a. Has il U ji t (H asil U ji Se cara Parsi al) 
Uji di gunakan untuk mengetahui pengaruh variabel $\mathrm{x}$ terhadap variabel $\mathrm{Y}$ seacara parsial, berikut hasilnya :

\section{Ta bel 5}

Ha sil U ji t (Par sial)

\begin{tabular}{|c|c|c|c|c|c|c|}
\hline \multicolumn{7}{|c|}{ Coefficients. } \\
\hline \multirow[t]{2}{*}{ Mode } & & \multicolumn{2}{|c|}{$\begin{array}{l}\text { Unstandardized } \\
\text { Coefficients }\end{array}$} & \multirow{2}{*}{$\begin{array}{c}\begin{array}{c}\text { Standardized } \\
\text { Coefficients }\end{array} \\
\text { Beta }\end{array}$} & \multirow[t]{2}{*}{$\bar{t}$} & \multirow[t]{2}{*}{ Sig. } \\
\hline & & $B$ & Std. Error & & & \\
\hline \multirow{4}{*}{1} & (Constant) & .372 & .211 & & \begin{tabular}{|l|}
1.765 \\
\end{tabular} & .083 \\
\hline & B & .213 & .105 & .230 & 2.028 & .047 \\
\hline & $P$ & .405 & .200 & .407 & 2.024 & .048 \\
\hline & M & .294 & .136 & .326 & 2.171 & .034 \\
\hline
\end{tabular}

Berdasarkan data di atas, dapat dilihat bahawa secara parsial budaya organisasi mempunyai kesan yang signifikan terhadap kinerja karyawan, secara parsial pelatihan memiliki pengaruh terhadap kinerja karyawan dan secara parsial motivasi memiliki pengaruh terhadap kinerja karyawan .

\section{b. Hasil Uji Simultan F}

\section{Tabel 6}

Hasil Uji t (Parsial)

\begin{tabular}{|c|c|c|c|c|c|c|}
\hline \multicolumn{7}{|c|}{ ANOXA." } \\
\hline \begin{tabular}{|l|l|} 
Model \\
\end{tabular} & & Sum of Squares & $d f$ & Mean Square & $\bar{F}$ & Sig. \\
\hline \multirow{3}{*}{1} & Regression & 11.994 & 3 & 3.998 & 109.555 & $.000^{\circ}$ \\
\hline & Residual & 2.044 & 56 & .036 & & \\
\hline & Total & 14.037 & 59 & & & \\
\hline
\end{tabular}

Dalam jadual analisis varians (Anova), keputusan ujian $\mathrm{F}$ dipaparkan yang dapat digunakan untuk meramalkan sumbangan aspek budaya organisasi, pelatihan dan motivasi kepada pemboleh ubah kinerja karyawan. Daripada pengiraan, nilai $\mathrm{F}$ yang dikira adalah 109,555. Dengan tahap penting $5 \%$ dan df $1=3$ dan df $2==56$, nilai $\mathrm{F}_{\text {table }}=3,54$ diperolehi. Oleh kerana nilai Fcount
$(109,555)>$ nilai jadual $\mathrm{F}(3,54)$, dapat disimpulkan bahawa dua pembolehubah bebas iaitu budaya organsasi, pelatihan dan motivasi menyumbang secara signifikan kepada pemboleh ubah kinerja karayawan. Sehingga model regresi yang diperoleh sesuai untuk digunakan untuk meramalkan. Kemudian dapat disimpulkan bahwa $\mathrm{H}_{\mathrm{o}}$ ditolak dan $\mathrm{H}_{\mathrm{a}}$ diterima .

\section{Hasil Koefisien Persamaan Regresi}

\section{Linier Beerganda}

Tabel 7

Hasil Koefisisen Regresi Linier

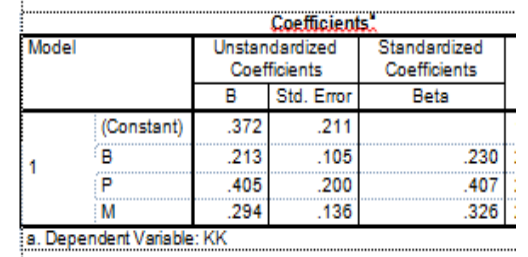

Berikut persamaan dari regresi linier berganda:

$Y=0,372+0,213 X_{1}+0,405 X_{2}+0,294 X_{3}$

Dalam persamaan regresi di atas menunjukkan nilai tetap 0,372 . Ini menyatakan bahawa jika budaya organisasi, pelatihan dan motivasi pembolehubah dianggap malar atau bernilai 0 (sifar), maka kinerja karyawan akan meningkat sebanyak 0,372 .

Pekali regresi pada pemboleh ubah budaya organisasi adalah 0,213 , ini bermakna jika pembolehubah budaya organisasi meningkat satu unit maka pemboleh ubah kinerja karyawan akan meningkat sebanyak 0,213. Perhatikan 
bahawa pembolehubah lain dianggap malar .

Pekali regresi pada pemboleh ubah pelatihan adalah 0,405 , ini bermakna jika pemboleh ubah pelatihan meningkat satu unit maka kinerja karyawan berubah-ubah akan meningkat sebanyak 0,405. Perhatikan bahawa pembolehubah lain dianggap malar .

Pekali regresi pada pemboleh ubah motivasi adalah 0,294 , ini bermakna jika pemboleh ubah motivasi meningkat satu unit maka kinerja karyawan berubah-ubah akan meningkat sebanyak 0,294 .

\section{Hasil Koefisien Determinasi $\left(R^{2}\right)$}

\section{Tabel 8}

Hasil Koefisisen Determinasi

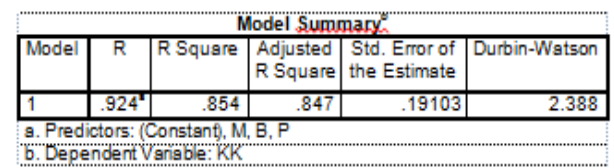

Dari tabel di atas dapat diketahui koefisien determinasi (R Square) sebesar 0,854 atau $85,4 \%$. Hasil tersebut memberi pengertian bahwa vaiabel dependen yaitu kinerja pegawai dapat dijelaskan oleh variabel independen yang terdiri dari budaya organsasi, pelatihan dan motivasi dengan nilai sebesar $85,4 \%$ sedangkan sisanya $14,6 \%$ dijelaskan oleh variabel independen lainnya yang tidak dimasukkan dalam model penelitian ini .

\section{KESIMPULAN DAN SARAN}

\section{A. Kesimpulan}

Berdasarkan hasil penyelidikan dan analisis yang dijelaskan dalam bab sebelumnya oleh penulis tentang pengaruh budaya kerja dan pelatihan terhadap kinerja karyawan di PT. Kenko No Kai, dapat disimpulkan oleh para peneliti, yaitu :

1. Berdasarkan keputusan ujian $t$ (sebahagian) didapati budaya organisasi mempengaruhi terhadap kinerja karyawan.

2. Berdasarkan hasil uji $\mathrm{t}$ (parsial) ditemukan bahwa pelatihan berpengaruh terhadap kinerja karyawan.

3. Berdasarkan hasil uji t (parsial) ditemukan bahwa motivasi berpengaruh terhadap kinerja karyawan.

4. Berdasarkan keputusan ujian F (serentak) didapati budaya organisasi, pelatihan dan motivasi mempengaruhi kinerja karyawan.

\section{B. Saran}

Peningkatan kinerja pegawai tentu tidak terlepas dari berbagai faktor yang mempengaruhi, seperti dalam penelitian ini setidaknya ada dua faktor yang secara signifikan mempengaruhi kinerja pegawai yakni budaya kerja dan pelatihan. Kedua faktor tersebut mempengaruhi kinerja baik secara parsial maupun simultan . 
Hasil penelitian ini menunjukkan bahwa budaya organisasi, pelatihan dan motivasi secara signifikan mempengaruhi kinerja pegawai di PT. Kenko No Kai. Terkait hasil penelitian ini maka kinerja pegawai dapat ditingkatkan melalui peningkatan dalam hal penerapan budaya organsasi, pelatihan dan motivasi .

\section{DAFTAR PUSTAKA}

Dessler, Gary. 2015. Manajemen Sumber Daya Manusia. Jakarta: Salemba Empat .

Ghozali, Imam. 2005. Aplikasi Analisis Multivariate dengan SPSS. Semarang: Badan Penerbit UNDIP .

Hasibuan, Malayu SP. 2017. Manajemen Sumber Daya Manusia. Bandung: Bumi Aksara .

Ilyas, Jaslis. 2002. Kinerja: Teori, Penilaian dan Penelitian. Depok: Pusat Kajian Ekonomi FKMUI

Krisnaldy, K., Pasaribu, V. L. D., \& Senen, S. (2019). Pengaruh Budaya Organisasi, Lingkungan Kerja Dan Iklim Organisasi Terhadap Motivasi Pegawai Serta Dampaknya Terhadap Kepuasan Kerja. Jurnal Semarak, 2(2), 164-183.

Mangkunegara, Anwar Prabu. 2015. Manajemen Sumber Daya Manusia Perusahaan. Bandung: Remaja Rosdakarya .

Pasaribu, V. L. D., Krisnaldy, K., \& Warasto, H. N. (2020). Pengaruh Gaya Kepemimpinan, Disiplin Kerja Dan

Kompensasi Terhadap $r$ Kinerja
Pegawai (Studi kasus kelurahan
Pisangan Ciputat). Jurnal Disrupsi
Bisnis: Jurnal Ilmiah $r$ Prodi
Manajemen, Fakultas Ekonomi,
Universitas Pamulang, 3(1).

Rivai, Veithzal. 2015. Manajemen Sumber Daya Manusia untuk Perusahaan. Depok: Rajawali Pers .

Robbins, Stephen P. 2014. Perilaku Organisasi (Organizational Behaviour). Jakarta: Salemba Empat .

Robbins, Stephen P dan Mary Coulter. 2012. Manajemen. Jakarta: Erlangga .

Sedarmayanti. 2011. Manajemen Sumber Daya Manusia, Reformasi Birokrasi dan Manajemen Pegawai Negeri Sipil. Bandung: Refika Aditama .

Siagian, P Sondang. 1995. Manajemen Sumber Daya Manusia. Jakarta: Elek Media Komputindo .

Supriyadi, Gering dan Triguno. 2001. Budaya Kerja Organisasi Pemerintah. Jakarta .

Thoha, Miftah. 2015. Perilaku Organisasi: Konsep Dasar dan Aplikasinya. Depok: Rajawali Pers .

Wirawan. (2009). Evaluasi Kinerja Sumber Daya Manusia Teori Aplikasi dan Penelitian. Jakarta. Penerbit: Salemba Empat .

Tjahjono, Binawan Nur dan Tri Gunarsih. 2012. Pengaruh Motivasi Kerja Dan Budaya Organisasi Terhadap Kinerja pegawai Di Lingkungandinas Bina Marga Propinsi Jawa Tengah. Jurnal Nasional . 
Safrizal dkk. 2014. Pengaruh Budaya Kerja, Kemampuan dan Komitmen Pegawai Terhadap Kinerja Pegawai Serta Dampaknya Pada Kinerja Dinas Pertambangan Dan Energy Aceh. Jurnal Nasional .

Triasmoko, Deni. 2014. Pengaruh Pelatihan Kerja Terhadap Kinerja Karyawan PT Pos Indonesia Cabang Kota Kediri. Jurnal Nasional .

Mora, Zulkarnaen dan Muhammad Riza. 2016. Pengaruh Budaya Organisasi, Pelatihan Dan Pengembangan Terhadap Prestasi Kerja Karyawan Pada BPRS ADECO Langsa. Jurnal Nasional .

Rokhman, Wahibur dan Amirul Fatihin. 2014. Pengaruh Pelatihan dan Budaya Organisasi Terhadap Efektivitas Kinerja Karyawan di Lembaga Keuangan Mikro Syariah Kabupaten Kudus. Jurnal Nasional.

Sari, Desi Rosiana dkk. 2016. Pengaruh Budaya Kerja Terhadap Kinerja Pegawai Pada Badan Kesatuan Bangsa Dan Politik Kabupaten Kutai Timur. Jurnal Nasional .

Sugiarti dkk. 2016. Pengaruh Pelatihan Kerja Terhadap Kinerja Karyawan Pada PT Padma Ardya Aktuaria Jakarta. Jurnal Nasional .

Uddin, Mohammad Jasim dkk. 2013. Impact of Organizational Culture on Employee Performance and Productivity: A Case Study of Telecommunication Sector in Bangladesh. Jurnal Internasional .

Sugianingrat, Ida Ayu dan I Wayan Gede Sarmawa. 2017. Effect Of Work Culture On Employee Performance With Work Motivation As Mediator:
Study At Nonstar Hotel In DenpasarBali, Indonesia. Jurnal Internasional .

Halawi, Ali dan Nada Haydar. 2018. Effects of Training on Employee Performance: A Case Study of Bonjus and Khatib \& Alami Companies. Jurnal Internasional . 